\title{
DEVELOPMENT OF INTERACTIVE MULTIMEDIA-BASED GYMNASTICS FLOOR TECHNIQUES LEARNING MODEL FOR JUNIOR HIGH SCHOOL STUDENTS
}

\author{
Ari WibowoKurniawan*, James Tangkudung** \\ Sport Science faculty, Malang State University* \\ Sport Science faculty, jakarta State University** \\ ar13_wibowo_k@yahoo.com* \\ jamestangkudung@unj.ac.id**
}

\begin{abstract}
Abstrack
Based on preliminary observations conducted on teachers and students of SMP Negeri in Malang Regency: (1) students can not and do not like the material gymnastics floor, and tend to like the material of big ball game (92\%); (2) students state that educators have never done teaching with media in the form of interactive multimedia, 100\%; and (3) students agree when done an development of interactive multimedia media for learning basic technique of gymnastic floor $100 \%$. The purpose of this research and development is to develop an effective model of basic techniques of floor gymnastics for junior high school students using interactive multimedia. In this study is using development research methods from Borg and Gall (1983: 775), and researchers did not use the whole but only using 7 steps. The 7 steps chosen by the researchers are as follows: (1) collecting information, (2) initial product design, (3) expert evaluation, (4) trial in phase I, (5) product revision (6) trials in phase II, (7) revisions and final products. Based on the result of data analysis of the evaluation of the learning expert is very valid, the evaluation of expert gymnastics is very valid, the evaluation of media expert is very valid. From the data analysis result of small group trial is valid enough $(73,1 \%)$, while large group trial is very valid $(85,75 \%)$, thus it can be concluded that the development of interactive multimedia-based floor gymnastic basic technique for junior high school student can be used..
\end{abstract}

Keywords: Development, learning, gymnastics floor, interactive multimedia

Physical education is an integral part of education in schools, which has the goal of improving the ability of students affectively, cognitive, psychomotor and social. Where this statement is supported by the AAHPERD formula, which essentially includes five items, namely: (1) a person who educated in physical education is a person who has knowledge and skills in relation to his body, and how the body is functioning, (2) physical education is a guarantee for health, (3) physical education can contribute to academic achievement, (4) Good physical education can contribute to the development of self-concept, (5) a good physical 
education program helps one to acquire social skills (Lutan, Rusli. 2002:5). From the formula, then an educator must be able to develop effective, efficient, enjoyable and safe physical education learning, so that the goal of physical education can be achieved.

The concept of physical education is also closely related to the education of recreation and health education, which produces the field of Penjaskes (Health and physical education) study, the combination of physical education and health education with the point of equality in the estuary of the goal is the formation of lifelong lifestyle to achieve health and well being. Nevertheless, at the practitioner level there is a complication, i.e. learning of penjaskes becomes uncertain in terms of substance and purpose, competition in the allocation of time for substantial submission, and ultimately leads educators to simply convey information and even non-functional knowledge.

In the subject of physical education in school, has some sports ramifications material that one of the materials is the material gymnastics floor. In general the purpose of this gymnastics floor is to train the body of a more capable and skilled person, but not only physically but also spiritually. In doing exercise or floor gymnastics learning required a special method, so that students are able to develop personality and physical fitness as well through learning gymnastics floor.

Learning materials of gymnastics floor at school, especially in junior high school, are rarely given during the learning process, given the media and learning activities that support for the implementation of learning is not adequate and not too much, whereas gymnastics floor can affect the performance of students to be able to move better and to improve Physical quality. So it takes creativity of an educator to develop a learning model and media to improve the student's ability to master the skills of gymnastics floor.

Whereas based on the students' books used in the lessons of Physical Education, Sport and Health for the 2013 curriculum lesson for Junior High School / MTS, there are materials of floor gymnastics, including: roll front, roll back, mermaid, tiger jump and lumber roll (Ministry of Education and Culture, 2014: 151). Based on preliminary observation and observation in SMP Negeri in Malang regency, it was found that learning method used by educator is giving example of movement of one of the whole floor gymnastic material then direct students instructed to try imitating the movement on the gym mat. Some students are afraid / dare not to do gymnastics on the floor, and most of the students are still wrong doing the technique of floor gymnastic material

Students who are usually not correct in performing the techniques of gymnastic floor should be given the correct learning techniques and learning model starting from the easiest level. Then the students will automatically have the ability to quickly master the learning materials gymnastics floor. In accordance with the theory of Tangkudung which states that the increase in the burden of training is very important, the correct loading exercises and increased training load will 
gradually improve the ability or skills to learn motion. (Tangkudung, 2012:17)

In addition a physical education educator, not maximal in applying learning materials gymnastics floor, this is one of them caused because the learning model taught to students still less in applying science and technology (IPTEK). But now there are so many diverse media of science and technology that can be used as a learning process. Therefore the use of science and technology in improving the ability of students today should be done.

According to researcher, learning strategies that educators do is less appropriate to be used to convey materials gymnastics floor. Therefore it needs a strategy for students to dare to do and not feel afraid with the stages and techniques help students, because "learning strategy is a form of activities by educators to convey messages or material to students, will increasingly attract children to actively play a role in physical education learning activities using variations in learning“ (Widijoto, 2010: 07). The statement is made clear by (Annarino, 1980: 176) "that the characteristics of seventh- and eighth-grade middle-aged children are a strong desire to learn skills and interest in technical subjects"..

The results of preliminary observations conducted in junior high schools in Malang Regency, From 50 participants have filled in the questionnaire can be concluded as follows, (1) students can not and less like the materials gymnastics floor, and tend to like materials that are game (92\%), (2)) students stated that educators have never done teaching with media in the form of interactive multimedia media, $100 \%$ (3) student can operate computer or laptop, 97\% (4) student agree when Conducted an interactive multimedia media development for learning the basic technique of $100 \%$ gymnastic floor.

While the results of observations of the researchers have been obtained the result that the method of learning used by educators give an examples of movement of one of the overall gymnastics material, then the students directly instructed to try imitating the movement on the gym mat. Most of the students are afraid / dare not to do gymnastics on the floor, and most of the students are still wrong doing the technique of floor gymnastic material.

Therefore, with the technology being developed, it can help students and educators to master the skills of gymnastics floor by self-study which is assisted with interactive multimedia learning gymnastics floor that will be fully packed, in order to facilitate the students. Thus, the researchers want to develop research with the title: "Development of Interactive Multimedia-Based Gymnastics Floor Techniques Learning Model for Junior High School Students".

The product developed in the form of basic technique of gymnastic floor using interactive multimedia, with product specification is learning of this gymnastic floor poured in the form of interactive multimedia.In this interactive Multimedia, there is a gymnastics learning guide, which contains steps that can facilitate learning of gymnastics floor.

According to Sugiyo (2008: 297) that research and development or in 
English Research and Development is the research used to produce a particular product, and test the effectiveness of the product.Then according to Sukmadinata (2005: 164) that research and development is a process or steps to develop a new product or refine products that already exist, which can be accountable. Meanwhile, according to Gay in Asim (2002: 1) explains the development research is an attempt to develop an effective product that used in school, not to test the theory.Dwiyogo (2004: 3) also provides an opinion that development research is a research oriented to produce or develop products, for example developing sports school model, developing curriculum of physical education, developing sports learning strategy / method, developing learning media of sports, developing sports learning textbook etc.

According to Anitah (2008: 1.1) "learning is an activity that has been formulated by the curriculum and there is interaction in learning that leads to good learning activities, so that learning goals can be achieved with the maximum". According to Rusdiani (2013: 73) "that learning is a process of interaction between learners with educators and learning resources in a learning environment". "Learning is basically an effort to facilitate students to be a person or individual in accordance with the expected competencies" (Asim, et al, 2012: 02)."Learning must have a good planning, which adheres to the principles of psychology, both about individual development and learning process so as to achieve the effectiveness of learning conducted" (Sumiati \& Asra, 2007: 05).

According to Mu'arifin (2001: 55) that the Learning of Physical Education, Sport and Health is not strange something to the student, as the activity of motion to be conducted in daily life, which is the embodiment of its basic characteristics, namely dynamic, active and adaptive. Physical education of sports and health is a process of interaction between physical education educators of sports and health with their students and learning resources concerning psychomotor, cognitive (knowledge) and affective aspects (attitude) as the embodiment of dynamic, active and adaptive student characteristics.

According to Sadiman (2003: 6) media is an intermediary or delivery of messages from the sender to the recipient of the message.Prastati (2001: 3) explains the meaning of the media is anything that can distribute information from information sources to the recipient information. According Arsyad (2002: 4), if the media that brings messages or teaching. Then the media is called the media of teaching.Learning media is everything that used to distribute the message (learning materials), so it can stimulate the attention, interest, thoughts and feelings of students in learning activities to achieve certain learning goals (Widijoto, 2006: 6).

Gagne and Briggs in Dwiyogo (2010: 229) argue that "learning media is a tool used for the delivery of teaching content (the media referred to here, such as books, tapes-recorders, tapes, films, videos, television slides, etc.)". According to AECT in Sadiman, et al (2003: 19) "learning media is software contains messages or educational information that usually presented with the use of equipment. While 
the equipment or hardware itself is a means to be able to display messages contained in the media. According to Hariyoko (2012: 54) "learning media is anything that can be used to distribute information from teacher to student, so that it can stimulate student's thoughts, feelings, concerns, and interests, and ultimately can make students perform learning activities efficiently and effectively".

Those meanings are clarified by Dwiyogo (2010: 229) "the media are all forms and vocations that can be used in a process of information distribution". There are two of media used for the delivery of teaching materials, namely print and non-print materials. "The teaching materials are in the form of textbooks, student manuals or workbooks, whereas non-print teaching materials are video, audio, etc." (Derektorat Ketenagaan, 2010: 01). According to Sadiman, et al (2003: 29) "print media / books with pictures / photographs is a common language, which can be understood and enjoyed everywhere". The purpose of the use of learning media is to streamline the process of communication in learning so as to achieve the desired goals.

Etymologically multimedia comes from the Latin, i.e. from the word "multi" which means a lot; Variety and "medium" which means something used to convey or bring something. According to opinion of Vaughan (1994: 4) multimedia is "various combinations of text, graphics, sound, animation, and video delivered using computers or other electronic devices". Rada (1995) argues that "multimedia refers to any synchronized media stream." An example of multimedia is the moving images that are in sync with sound (including modern television and movie broadcasts) (Green \& Brown, 2002: 2). Heinich, Molenda, Russell \& Smaldino (1999: 229) argues, "multimedia refers to the various combinations of two or more integrated media formats into information or instruction programs".

Gymnastics floor is a sport activity that relies on body flexibility. It is said gymnastics floor because all the movement skills are done on the floor mattress grounded without involving other tools. Muhajir (2007: 69) states gymnastics floor is one of the sports that rely on the activities of all members of the body, both for sports gymnastics itself and for other sports. Therefore, gymnastics is also referred to as basic sports. Gymnastics refers to motion performed with an integrated combination and incarnate from every part of the body of the ability of motor components / motion such as strength, speed, balance, agility, and accuracy.

Here are all kinds of gymnastic floor taught in junior high school and explanation how to do it (Soekarno, 1986: 137).

The front rolling is the rolling done to the front. The steps to do rolling to the front: (a) Stand upright, both hands straight at the side of the body. (b) Raise your hands to the front, bend down, and place your palms on the mat. (c) Elbow to the side, insert the head between two hands. (d) Touch your shoulders to the mat. (e) Roll to the front. (f) Fold both knees, pull the chin and knee to the chest with the position of the hand embrace the knee. $(\mathrm{g})$ The final rolling attitude is squatting, and then stands up straight. 


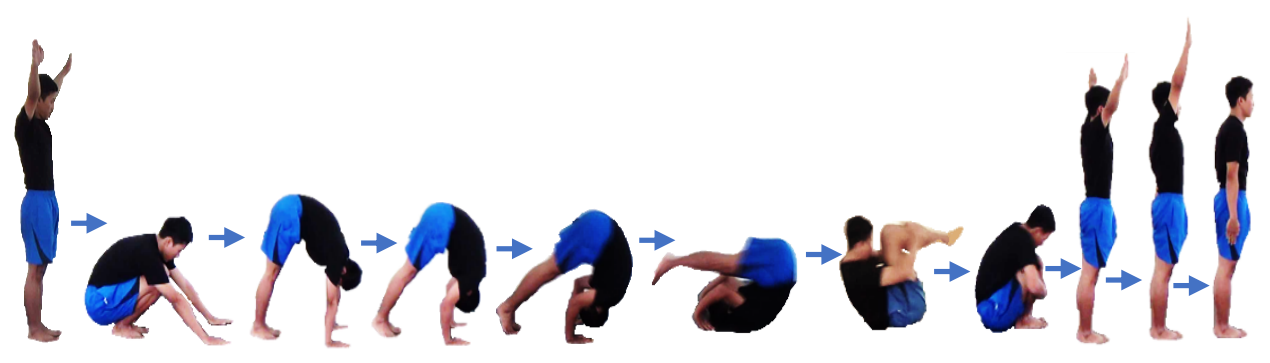

Figure 1. Front Roll Movement

(Source: Author, 2016)

The back roll has the following movements: (a) the position of squatting, both legs tight, and heel lifted. (b) Head down and chin closer to chest. (c) Both hands are beside the ears and palms facing up. (d) Drop the buttocks back, keep the body round. (e) As the back touched the mat, both knees were quickly pulled back of the head. (f) At the moment the two toes touch the mat behind the head, the palms press the mat until the hands are straight and the head is raised. (g) Take a squat attitude, straight ahead parallel to the shoulders, and then stand up.

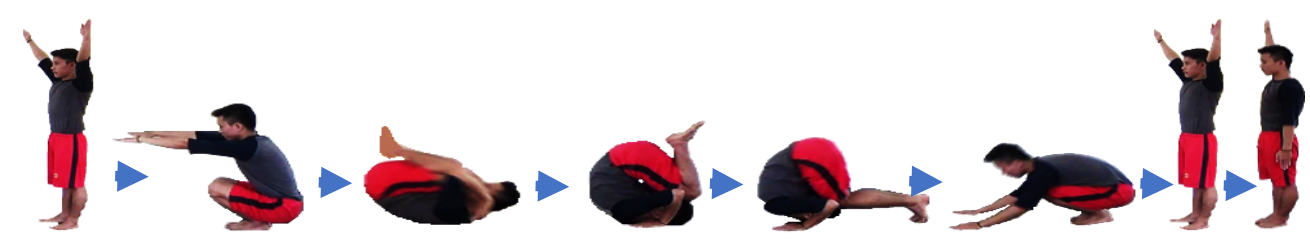

Figure 2. Back Roll Movement

(Source: Author, 2016)

Tiger jump, how to do it as follows: (a) Stand straight, arms straight on the sides, straight ahead. (b) Both legs refuse on the backboard with swings up arms, body floating, hands rest on the easel, and the view is centered in front by hand. (c) Both hands refuse with all their strength and knees in the fold to the chest. Straighten your legs as you are above the ends of the easel. (d) The final attitude of squatting continues to stand.

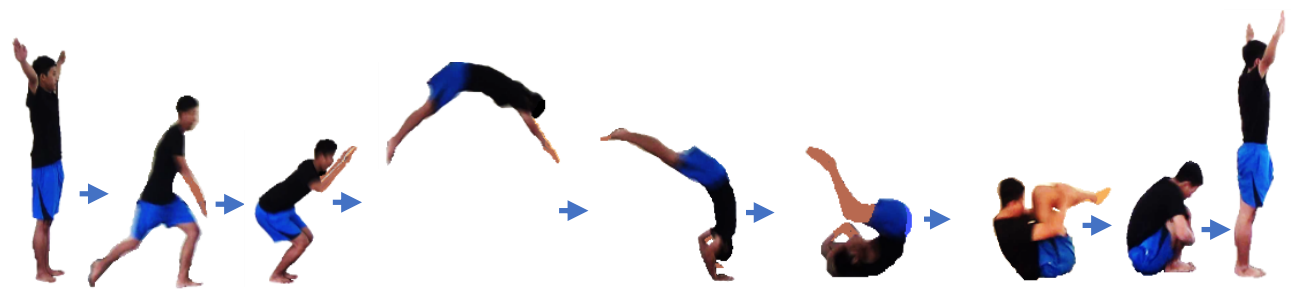

Figure 3. Tiger Jump Movement

(Source: Author, 2016)

Radsclag/ Cartwheel is the movement of the body twisted from a sideways 
attitude with the pedestal of movement on both feet and hands. Exercise Cartwheel can be done in stages, as follows: (a) First, it stood sideways, both legs opened slightly wide, both hands straight up sideways to the side (resembling the letter V) and foresight. (b) Then drop the body to the left side, place your palms to the left side, then the right leg lifted straight up, followed by placing the palm of the hand next to the left hand. (c) When the right leg is swung, then the left leg is rejected on the floor, so both legs are open and sideways to the side. (d) Then place the right foot to the side of the right hand, left hand lifted followed by putting the left foot on the side of the right foot. (e) Body up, both arms straight up to the original position.

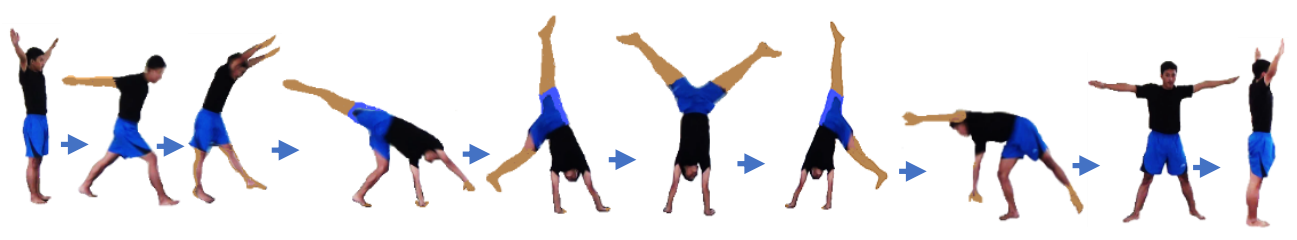

Figure 4.Radsclag/Cartwheel Movement

(Source: Author, 2016)

Neck spring has the following stages of movement: (a) the initial attitude, standing straight with both legs tight and both arms raised straight up. Bending over, keep your hands on the mattress about one foot step away, after that place the nape between both hands while taking the front rolling position. Both feet are kept straight. (b) When the position for the front roll is achieved, immediately roll to the front, when the body is above the head, both feet immediately whipped straight ahead while assisted by both hands pushing the body by pressing the mat. This discharge causes the body to bounce to the frant. (c) When the floating is complete, both feet immediately leveled. The body remained bouncy and both arms held straight. Finally, stand up straight.

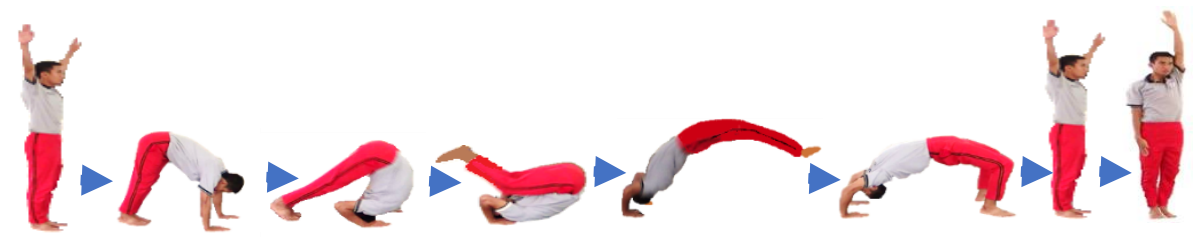

Figure 5. Headspring

(Source: Author, 2016)

\section{METHODOLOGY}

In this study, researchers used a development research model from Borg and Gall (1983: 775). And from research and development steps Borg and Gall, the researcher makes simple modifications. It is based on the adjustment of time and where to do research development. Modifications made by researchers as follows: 
(1) The collection of information, (2) Preparing an initial product, (3) evaluation of experts, (4) Trial phase I, (5) Revision products, (6) Trial of the phase II, (7) Revision and final products. Procedure of learning development of gymnastics floor using interactive multimedia for junior high school student in Malang Regency, researcher make chart of research step, that is as follows:

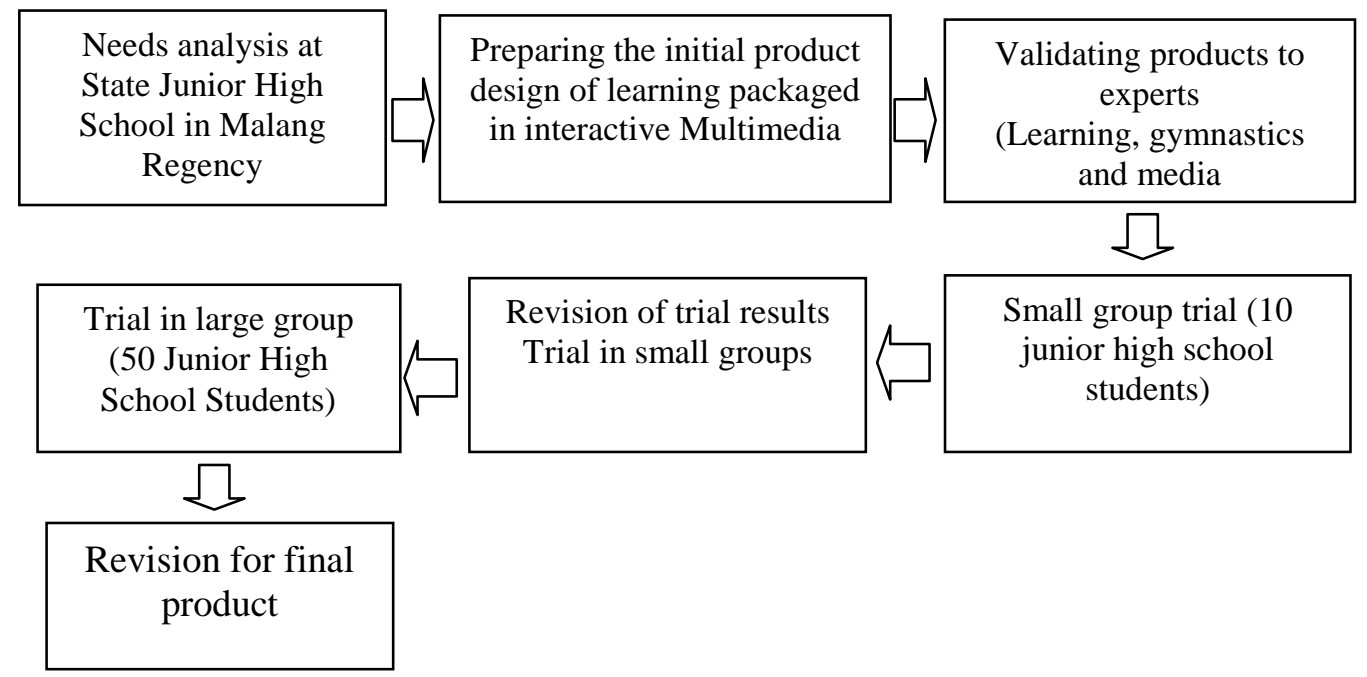

Figure 6. Chart of Development Procedures

\section{Trial Subject}

The subjects used in this research and development, as follows: (a) The subjects of initial research (needs analysis) are, teachers of physical education in Junior High School, sports, and health in Malang Regency. (b) The subject of an expert's evaluation is an educational expert, a gymnast, and a media-learning expert. (c) Subject of trial in phase I (small group trial), SMP Negeri 1 and 2 Pagak, Kab. Malang. Used by 10 junior high school students using random sampling method. (d) The subjects of trial in large group, 2 (two) State Junior High School in Malang regency, namely SMP Negeri 1 and 2 Pagak, Using the trial subjects of 50 students of SMP Negeri in Malang regency.

\section{Data analysis technique}

In this research development of data analysis technique used is quantitative descriptive analysis technique with percentage. This technique is used to analyze quantitative data obtained from the results of questionnaire evaluation distribution of the experts and the subject of the results of the developed product. According to Akbar and Sriwiyana (2010: 213) the formula for processing data in the form of descriptive quantitative analysis percentage is as follows: 
Notes:

$$
\begin{aligned}
& V=\frac{T S E V}{S-\max } \times 100 \% \\
& \text { V : Validity } \\
& \text { TSEV : Total of Empirical Validator Score } \\
& \text { S-max : Maximum Scores Expected } \\
& 100 \% \text { : Constant number }
\end{aligned}
$$

To simplify the conclusion of the results of percentage analysis, the results obtained then classified data in accordance with the percentage obtained. According to Akbar and Sriwiyana (2010: 153) the percentage classification to be used is:

Table 1. Product Quality Criteria

\begin{tabular}{|l|l|l|}
\hline Percentage & Notes & Meaning \\
\hline $86-100 \%$ & Very Valid & Used Without Revision \\
\hline $70-85 \%$ & Valid enough & Used With Small Revisions \\
\hline $60-69 \%$ & Less Valid & Less Adequate to Use is Suggested Not Used \\
\hline $00-50 \%$ & Invalid & Can not be used \\
\hline
\end{tabular}

(Source: Akbar and Sriwiyana, 2010:153)

\section{RESULT}

\begin{tabular}{|c|c|c|}
\hline No. & Component & Finding \\
\hline 1. & Introduction Study & \\
\hline & $\begin{array}{l}\text { a. Needs analysis of } \\
\text { the instrument } \\
\text { given to the } \\
\text { teacher } \\
\text { containing } 6\end{array}$ & 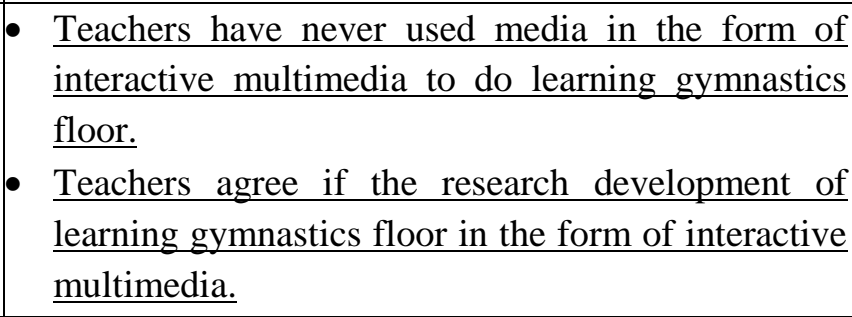 \\
\hline & 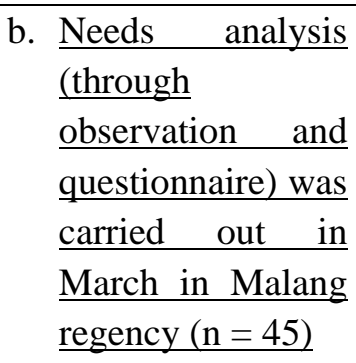 & $\begin{array}{l}\text { - } 45 \text { participants have completed questionnaires, (1) } \\
\text { students like multimedia in the form of interactive } \\
\text { multimedia } 94 \%,(2) \text { students stated that teachers } \\
\text { have never done learning with media even } \\
\text { interactive multimedia, } 82 \% \text { (3) students said } \\
\text { students can operate computer or laptop, 97\% (4) } \\
\text { students agree when done an interactive multimedia }\end{array}$ \\
\hline
\end{tabular}

Based on data collection conducted by researchers in research and development of learning gymnastics floor using interactive multimedia media for junior high school students in Malang Regency was obtained data as follows.

Table 2. Data Study Results of Introduction, Expert Evaluation, and Trial 


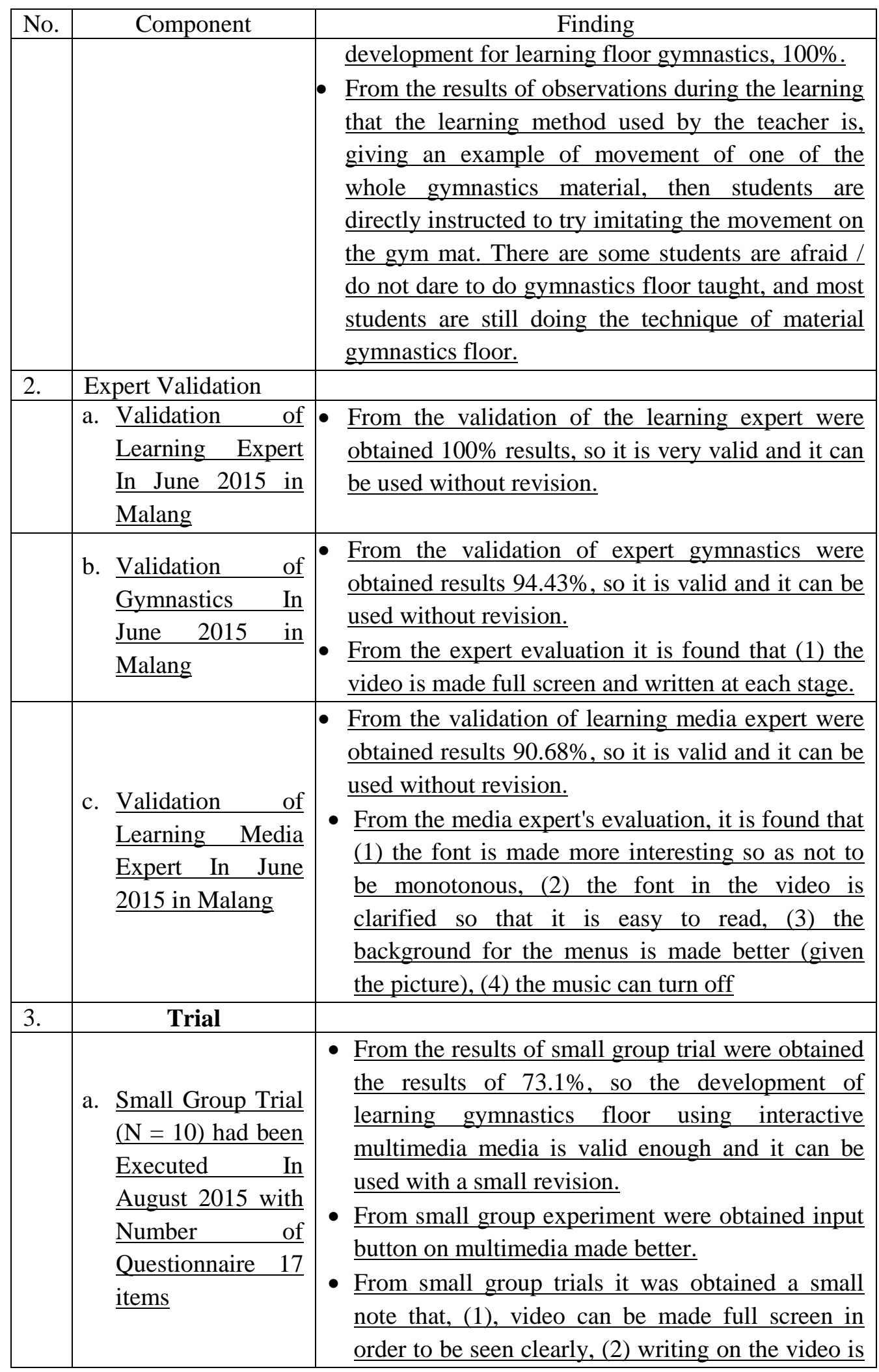




\begin{tabular}{|c|c|c|}
\hline No. & Component & Finding \\
\hline & & colored \\
\hline & 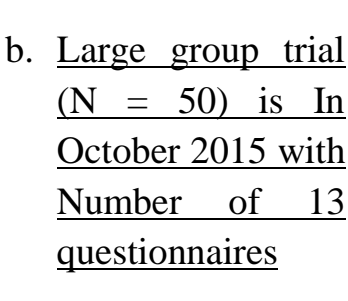 & 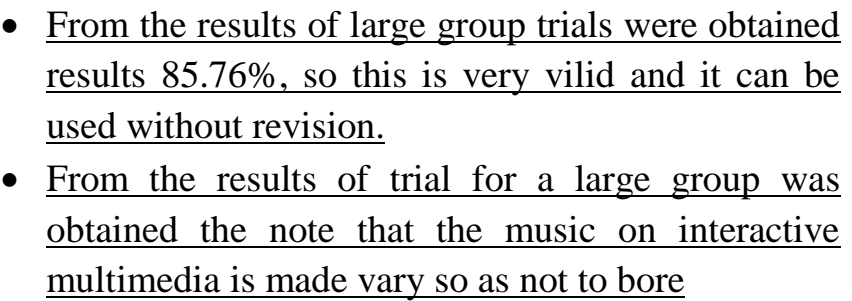 \\
\hline
\end{tabular}

Table 3 presents data from the results of validation of learning expert on product development design of floor gymnastics learning using interactive multimedia media

Table 3. Data of Expert Validation Results $(n=1)$ with 12 question instruments

\begin{tabular}{|c|l|l|l|l|c|}
\hline No. & \multicolumn{1}{|c|}{ Expert } & $\underline{\text { Minimum }}$ & $\underline{\text { Maximum }}$ & $\underline{\underline{\text { Results }}}$ & Percentage \\
\hline$\underline{\text { Score }}$ & $\underline{\text { Learning }}$ & $\underline{12}$ & $\underline{48}$ & $\underline{\text { Score }}$ & $\underline{48}$ \\
\hline & $\underline{\text { Expert }}$ & $\underline{\text { Average }}$ & & & $\underline{100}$ \\
\hline
\end{tabular}

Based on table 3 it can be seen that the average percentage of the results of validation of learning experts is $100 \%$. Learning experts have considered the research done by researchers is very good because it was evidenced that the learning experts provide $100 \%$ validation.

Table 4 presents the data of gymnastics validation results on the development of gymnastics floor learning is using interactive multimedia media.

Table 4. Data on Validation Result of Expert Gymnastic $(n=1)$ with 12 question instruments

\begin{tabular}{|c|l|l|l|l|l|}
\hline No. & \multicolumn{1}{|c|}{$\underline{\text { Expert }}$} & $\underline{\underline{\text { Minimum }}}$ & $\underline{\text { Maximum }}$ & $\underline{\underline{\text { Results }}}$ & Percentage \\
\hline$\underline{\text { Score }}$ & $\underline{\text { Gymnastics }}$ & $\underline{12}$ & $\underline{48}$ & $\underline{\text { Score }}$ & $\underline{46}$ \\
\hline & $\underline{\text { Expert }}$ & $\underline{\text { Average }}$ & & & $\underline{95.83}$ \\
\hline
\end{tabular}

Based on table 4, it can be seen that the average percentage of experiment validation is $94.43 \%$. Suggestions on the results of the development of gymnastics 
floor learning using interactive multimedia media are as follows: (1) Gymnastics Expert, suggesting a full-size video or later writing in clarity so that students can easily understand motion by motion, (2) the writing oer stage is displayed on the screen to make it easy for the student to maximize the motion.

Table 5 presents data from media experts validation results of learning development of floor gymnastics using interactive multimedia media.

Table 5. Data of Media Validation $\operatorname{Expert}(n=1)$ with 34 question instruments

\begin{tabular}{|c|c|c|c|c|c|}
\hline No. & Expert & $\begin{array}{l}\text { Minimum } \\
\underline{\text { Score }}\end{array}$ & $\begin{array}{l}\text { Maximum } \\
\underline{\text { Score }}\end{array}$ & $\begin{array}{l}\text { Results } \\
\text { Score }\end{array}$ & Percentage \\
\hline 1. & Media Expert & $\underline{34}$ & $\underline{136}$ & $\underline{122}$ & 90.44 \\
\hline & Average & & & & 90.68 \\
\hline
\end{tabular}

Based on table 5 it can be seen that the average percentage of media expert validation results is $90.68 \%$. Suggestions on the results of the development of floor gymnastics learning using interactive multimedia media are as follows: (1) the fonts are made more interesting so as not to be monotonous, (2) the fonts on the video are clarified so that they are easy to read, (3) the background for the menus is made better (given the picture), (4) the music can be turned off.

Table 6 presents the processing of overall data of small group trial results and large group trials of product development design of gymnastics floor using interactive multimedia media, with a number of questionnaire instruments for small group trials of 17 questions, and large group trials 13 questions. In small group trials using 10 students of class VII, VIII, IX, and large group trials of 50 students of class VII, VIII, IX.

Table 6. Overall Data of Small Group Trials and Large Group Trials with Instruments in the form of Questionnaires for Small Group Trial As many as 17 Questions, and Large Group Trial As many as 13 Questions.

\begin{tabular}{|l|l|l|l|l|l|}
\hline$\underline{\text { No. }}$ & \multicolumn{1}{|c|}{ Component } & $\underline{\underline{\text { Minimum }}}$ & $\underline{\underline{\text { Maximum }}}$ & $\underline{\underline{\text { Results }}}$ & Percentage \\
\hline$\underline{\text { Score }}$ & $\underline{\underline{\text { Small Group Trial }}}$ & $\underline{170}$ & $\underline{680}$ & $\underline{497}$ & $\underline{73.1}$ \\
\hline$\underline{\text { with } \mathrm{n}=10}$ & $\underline{\underline{\text { Large group trial }}}$ & $\underline{650}$ & $\underline{2600}$ & $\underline{2221}$ & $\underline{85.75}$ \\
\hline$\underline{\text { with } \mathrm{n}=50}$ & $\underline{\text { Average }}$ & & & & $\underline{\mathbf{7 9 . 4 2}}$ \\
\hline
\end{tabular}

Based on table 6 it can be seen that the average percentage of small group trial validation results and large group trials is $79.42 \%$. 
From small group or large group experiment is found that (1) video can be made full screen in order to be seen clearly, (2) writing on video is colored, (3) music is made varies. (4) the addition of the portion of trying all the movements, so that when performing stages, four students are more able and courageous, and improving students' skills, (5) students with low basic skills at first feel fear and difficulty in doing gymnastics floor movement. But after the stages and how to help in interactive multimedia, students become enthusiastic to perform the activities of gymnastics floor.

\section{DISCUSSION}

The basic technique of gymnastics floor for junior high school students is a development conducted by researchers, in order to facilitate students to learn and practice. And this is in accordance with the theory of the following sources. According to Anitah (2008: 1.1) "Learning is an activity that have been formulated by the curriculum and there is interaction in learning that leads to good learning activities, so that learning objectives can be achieved with the maximum". According to Rusdiani (2013: 73) "That learning is a process of interaction between learners with educators and learning resources in a learning environment". "Learning is basically an effort to facilitate students to be a person or individual in accordance with the expected competencies" (Asim, et al, 2012: 02)."Learning must have a good planning, which adheres to the principles of psychology, both about individual development and learning process so as to achieve the effectiveness of learning conducted" (Sumiati \& Asra, 2007: 05).

Learning media developed by this researcher is a medium that used to facilitate students to receive materials gymnastics floor, and in accordance with theories from some of the following sources. According to Sadiman (2003: 6) media is an intermediary or delivery of messages from the sender to the recipient of the message.Prastati (2001: 3) explains the meaning of the media is anything that can distribute information from information sources to the recipient information. According Arsyad (2002: 4) if the media brings messages or teaching, then the media is called the media of teaching.Learning media is everything that used to distribute the message (learning materials), so it can stimulate the attention, interest, thoughts and feelings of students in learning activities to achieve certain learning goals (Widijoto, 2006: 6). Gagne and Briggs in Dwiyogo (2010: 229) argue that "learning media is a tool used for the delivery of teaching content (the media referred to here, such as books, tapes-recorders, tapes, films, videos, television slides, etc.)". According to AECT in Sadiman, et al (2003: 19) "learning media is software contains messages or educational information that usually presented with the use of equipment. While the equipment or hardware itself is a means to be able to display messages contained in the media. According to Hariyoko (2012: 54) "learning media is anything that can be used to distribute information from teacher to student, so that it can stimulate student's thoughts, 
feelings, concerns, and interests, and ultimately can make students perform learning activities efficiently and effectively".

While packaging the results of this research in the form of interactive multimedia, and this product are very helpful for students in learning basic techniques of gymnastics floor. Interactive multimedia is now increasingly recognized as a way to solve educational problems, both in developed and developing countries. In accordance with Rosenberg in Sutopo (2013: 28) stressed that interactive multimedia refers to the use of Internet technology to transmit a range of solutions that can improve knowledge and skills. The definition of interactive multimedia is the delivery of learning materials through an electronic media such as the Internet in a more flexible way to support and improve teaching, learning and assessment (Permana, 2006).

\section{CONCLUSION}

Based on the result of research and development of basic technique of gymnastics floor for junior high school students based on interactive multimedia, it can be concluded several things, among others: (1) Students can be helped by the learning stages that are developed, so enthusiastically follow the learning of gymnastics floor and students quickly master the learning well, (2) this interactive multimedia developed is easy to learn and very interesting for students, and(3) interactive multimedia can be used as a reference or teacher guidance in teaching, before students practice directly.

\section{REFRENCES}

Akbar,

S. \&Sriwiyana,

H. 2010.PengembanganKurikulumdanPembelajaranIlmuPengetahuanSosial (IPS). Yogyakarta: Cipta Media.

AndidanZhuang.(2003). Multimedia interaktifKonsepdanAplikasi. Jakarta: PT. Raja GrafindoPersada.

Ardhana,

Wayan.

2002.

KonsepPenelitianPengembanganDalamBidangPendidikandanPembelajara $n$. Malang: UniversitasNegeri Malang.

Arikunto, S. 1998. ProsedurPenelitianSuatuPendekatanPraktekEdisi VI. Jakarta: PT AsdiMahasatya.

ArsyadAzhar, 2002. Media Pembelajaran. Jakarta: PT. Raja GrafindoPersada. Asim, 2002. "LangkahlangkahPenelitianPengembangan "DisajikandalamLokakaryaNasionalAng kata II, MetodologiPenelitianPengembanganBidangPendidikandanPembelajaran. Malang: UniversitasNegeri Malang. 
Asmoro, DwiJoko, 2008. PenelitianPengembangan.p.1, (online) (http://www.geocities.com/dwijoeas/penelitianpengembangan.htm). (diakses 2 Maret 2015).

Borg. W. R \& Gall, M. D, 1983. Educational Research An Introduction. New York : Longman.

Brick Lynne, 2002.Bugardengansenamaerobik. Jakarta. PT. RajagrafindoPersada.

Depdikbud, 1995.TesKesegaranJasman Indonesia UntukRemaja 13-15 Tahun. Jakarta. PusatKesegaranJasmani Dan Rekreasi.

Dwiyogo, W. 2004. "KonsepPenelitian\&Pengembangan", DisajikanpadaLokakaryaMetodologiPenelitianJurusanKepembelajaranFak ultasIlmuKeolahragaanUniversitasNegeri Semarang Malang :UniversitasNegeri Malang.

Dwiyogo,

W.

2002." LangkahlangkahPenelitianPengembangan’DisajikandalamLokakaryaNasionalAng kata II, MetodologiPenelitianPengembanganBidangPendidikandanPembelajaran (Malang: UniversitasNegeri Malang.

Dwiyogo, W. 1991.PengetahuanKesegaranJasmani (SuatuPengantar). Malang: IKIP Malang.

Kemenegpora, 2007.Undang-UndangRepublik Indonesia Nomor 3 Tahun 2005;TentangSistemKeolahragaanNasional. Jakarta: Kemenegpora.

Kemendiknas, 2003. Undang-undangRepublik Indonesia Nomor 20 tahun 2003 TentangSistemPendidikanNasional. Jakarta: Kemendiknas.

Lastopo.2009. Pengertian Media Pembelajaran.p.1, (online). (http://students.blog.unnes.ac.id/lastopo/2009/05/02/media-audiovisual). (diakses 2 Mei 2015).

Mutohir, Toho Cholik, 2007. Sport Development Index (Konsep, Metodologi, danaplikasi). Jakarta: PT. Indeks.

Muhajir. 2007. PendidikanJasmani, Olahraga, danKesehatan SMP Kelas VIII. Jakarta: Yudhistira.

Prastati, T. 2001. Media Sederhana. Jakarta. DepartemenPendidikanNasional.

Purbo, Onno W. 2002.2 Multimedia interaktifdanPendidikan.ArtikelDalamCakrawalaPendidikanUniversitas Terbuka.

Pusatkesegaranjasmanidanrekreasi, 1999.TesKesegaranJasman Indonesia UntukRemaja 13-15 Tahun. Jakarta. DepartemenPendidikanKebudayaan.

Putrantana,

A.B.

2014.

PengembanganpembelajaranSenamLantaiMerodaMenggunakanMetode Part-Whole UntukSiswaKelas VII di SMP Negeri 18 Malang.Skripsitidakditerbitkan. Malang: PPs UM. 
Sadiman, Arif. S, 2003.Media PendidikanPengertian, Pengembangan, danPemanfaatannya. Jakarta: PustekomDikbud.

Setyosari, P. 2011. PembelajaranBebasisElektronik. Jakarta: PT. Raja GrafindoPersada.

Soekarno, W. 1986.TeoriPraktekSenamDassar. Yogyakarta: PT IntanPerwira.

Sudjana.1990. PenilaianHasil Proses BelajarMengajar. Bandung: P RemajaRosdakarya.

Sugiyo, 2008.MetodePenelitianKuantitatif, Kualitatifdan $R \&$ D. Bandung: Alfabeta.

Sukmadinata, 2005.MetodePenelitianPendidikan. Jakarta: PPs UPI dan PT RemajaRosdakarya.

Sutopo,

A.H.

2012.

TeknologiInformasidanKomunikasidalamPendidikan.Grahallmu.

Tangkudung, James. 2012. KepelatihanOlahraga "PembinaanPrestasiOlahraga". Jakarta: PenerbitCerdas Jaya.

Widijoto, H. 2006. BukuPetunjukTeknisPraktikPengalamanLapangan. Malang: UniversitasNegeri Malang.

Widijoto, H. 2008. KarakteristikPembelajaranBidangStudiPendidikanJasmani. MakalahdisajikandalammatakuliahPembelajaranPendidikanJasmani semester genap 2008/2009, Malang: UniversitasNegeri Malang.

Widijoto, H. 2009. KajianPengembanganKemampuanfisikMotorikanakusiadini. MakalahDisajikanDalamperkuliahan S1 PG PAUD.

Wikipedia. 2014.

PembelajaranOlahraga. (Online)(http://id.wikipedia.org/wiki/olahraga). (diakses 2 Maret 2015).

Wikipedia.

2014.

PembelajaranElektronik.(Online).http://id.wikipedia.org/wiki/Pembelajara n_elektronik), (diakses 2 Maret 2015). 